Dr Vitomlr Miladinovic, pukovnik, dipl. inž.

\section{Primena metoda ekspertskih mišljenja u prognoziranju i pripremi za donošenje odluka}

Metode ekspertskih ocena su značajne u prognozama kod izrade planova razvoja i u pripremanju znaçajnih strateskih odluka. Sustina im je u tome sto se stavovi zasnivaju na osnovi mišljenja eksperata, iza kojih stoji intuicija, strucnost, znanje i iskustvo, čime se nadomešta nedostatak kvantitativnih pokazatelja.

Kroz dugogodišs̆ju praksu razvijen je veliki broj intuitivnih metoda, a najznaçajnije su Brain storming-konferencija ideja, Filips 66, Sinektika, Brajin rejting, Delfi i SEER. Osnovne metodološke, stručne $i$ organizacione forme primene ovih metoda prezentirane su na način koji daje njihovu teoretsku osnovu i mere za primenu u praksi.

\title{
Uvod
}

U poslednje tri decenije došlo je do sve značajnije primene i razvoja najraznovrsnijih metoda i tehnika za prognoziranje naučnog i tehnološkog progresa, kao i za optimizaciju programske orijentacije. Težište je na dugoročnom prognoziranju, ali se koriste i u pripremi odluka strateškog nivoa.

Kod podela metoda prognoziranja u vojsci, Cujev (L.1) izdvaja heuristicke, matematičke i kombinovane metode prognoziranja. U metode heuristike ubraja obradu rezultata ekspertskih procena, a matematičke metode deli na statístičko prognoziranje, matematičko modeliranje i prognoziranje skokovitih promena. Dobivanje pouzdenije prognoze uzimanjem u obzir rezultata ekspertskih ocena i matematickog prognoziranja predstavlja kombinovano prognoziranje.

Metode ekspertskih ocena značajne su u sklopu prognoza ili priprema odluka, za sve slucajeve kada se ne može doći do kvantitativnih pokazatelja. Vode poreklo od anketa, snimanja i testova koji su primenjivani u psihologiji, sociologiji i ispitivanju javnog mnjenja. Suština ovih metoda je u tome što se zaključci formiraju na osnovu stavova eksperata za određena pitanja. Prema tome, u prvi plan dolazi rešavanje pro- blema intuitivnom metodom. Međutim, iza intuicije stoji stručnost, znanje i iskustvo eksperata. Na pitanje koliko su tako dobijeni odgovori prihvatljivi, treba istaći činjenicu da je nauka oduvek poznavala i koristila procene. U statistici se, na bazi uzorka, procenjuju asobine osnovnog skupa.

Metodi ekspertskog mišljenja sve više se koriste i u našoj armiji. Najvažniji razlozi su:

- složeni procesi, u koje spada $\mathrm{i}$ razvoj armijske organizacije, koji u velikoj meri karakterišu kvalitativne informacije;

- sve je više stručnjaka i rukovodećeg kadra koji poznaje i koristi metode ekspertskog ocenjivanja i prognoziranja;

- strategijsko odlučivanje i planiranje sve više dobija na značaju, a strategijski ciljevi se uopštenije definišu na bazi kvalitativnih informacija kojima raspolažu eksperti;

- istoriju i tendencije razvoja pojava eksperti najbolje poznaju.

Eksperti u svojim ocenama koriste sistemski pristup, što obezbeđuje celovitije sagledavanje interakcija, kao i mogućnost korišcenja mišljenja eksperata graniěnih disciplina. 
Radi upoznavanja sa dosadašnjim iskustvima izložićemo organizaciju, metode koje se koriste u ekspertskom prognoziranju, odnosno pripremanju odluka i metode obrade podataka ankete.

\section{Organizovanje ekspertskog prognoziranja i priprema odluka}

Praktična primena metoda ekspertskih mišljenja vezana je za višse faza, od kojih su najvažnije:

- izbor eksperata;

- karakteristike i način postav1janja pitanja;

- mogućnosti vrednovanja i ocene pouzdanosti (L.2).

\section{Izbor eksperata}

Izbor eksperata predstavlja izuzetno značajan problem. Eksperti bi trebalo da udovoljavaju sledećim zahtevima:

- poznavanje ispitivane teme;

- sposobnost uočavanja problema;

- kreativnost $i$ intuitivnost;

- sposobnost predviđanja;

- nepristrasnost i realnost;

- motivisanost za rešavanje problema.

Teško je očekivati da će svi eksperti udovoljavati svim zahtevima. Postoje i pokušaji uvođenja raznih pokazatelja za izbor eksperata. Takvi su, na primer, pokazatelji kompetencije i pouzdanosti.

Razlikuje se objektivni i subjektivni pokazatelj kompetentnosti. Objektivni pokazatelj utvrđuje se sistemom pitanja o zvanju, praksi, radovima i drugim karakteristikama kandidata. Za vrednovanje se koristi skala od 0 do 10. Subjektivni pokazatelj utvrđuje se ocenjivanjem sopstvene kompetencije od strane samih kandidata, na istoj skali. Zbrajanjem se dobija konačna ocena.
Pokazatelj pouzdanosti takođe se koristi. Utvrđuje se kao apsolutan i relativan. Apsolutni pokazatelj pouzdanosti treba da pokaže u kom stepenu se ostvaruju stavovi dotičnog eksperta. Relativni pokazatelj treba da pokaže njegovu pouzdanost u odnosu na prosek grupe. Poželjan broj eksperata je iznad 30, a minimalan 15-20. Ukoliko ih ima dovoljno, biraju se oni iznad proseka pouzdanosti grupe (L.3, L.4).

U praksi najěešce se koristi metod izbora eksperata na osnovu predloga jednog ili manje grupe poznatih eksperata. Ukoliko se raspolaže dovoljnim brojem potencijalnih eksperata može se primeniti i metoda slučajnog izbora.

Karakteristike $i$ način

postavljanja pitanja

Sastavljanje pitanja treba da udovolji sledećim najvažnijim zahtevima:

- ekspertu treba postaviti pitanja čije rešavanje odgovara njegovim specijalističkim znanjima;

- redosled pitanja i njihova formulacija mora biti logična i celishodna;

- na eksperta se ne može prebaciti zadatak formulisanja pitanja i prikupljanja građe;

- pitanja moraju biti jednoznačoa i jasna;

- pitanja treba da omoguće jednostavno odgovaranje u relativno kratkom vremenu.

Pitanja mogu biti razlicita po svom tipu. Uglavnom se razlikuju pitanja: - koja se odnose na vreme ili vremenski interval; - koja predstavljaju izbor ispravnog odgovora; - koja se odnose na klasiranje pojava po određenim kriterijumima; - koja zahtevaju numeričku procenu količine ili verovatnoće pojave; - koja zahtevaju analizu situacije; — koja zahtevaju analizu posledica; - koja zahtevaju rangiranje, i ona - koja zahtevaju opisani odgovor (L.2). 
Pri određivanju značaja pojedinih pokazatelja ili klasiranja pojava, svakom kriterijumu se pripisuje odgovarajuća težina, tj. subjektivno određena mera relativme važnosti. Određivanje relativne važnosti je prilično složeno, jer postoji poteškoća da se osećanja i iskustva provedu u numeričku vrednost. Jedan od mogucíh naǒina numeričkog poređenja je takozvana metoda parne ocene superiornosti (inferiornosti) više kriterijuma, koja se dostavlja $u$ sklopu ankete ekspertima.

Tabela

Ocena relativne važnosti kriterijuma

\begin{tabular}{|c|c|}
\hline Ocena & $\begin{array}{l}\text { Karakter odnosa važnosti } \\
\text { kriterijuma }\end{array}$ \\
\hline 1 & Kriterijumi jednake važnosti \\
\hline 3 & $\begin{array}{l}\text { Neznatni prioriteti jednih u odno- } \\
\text { su na druge }\end{array}$ \\
\hline 5 & $\begin{array}{l}\text { Znatan prioritet jednih u odnosu } \\
\text { na druge }\end{array}$ \\
\hline 7 & Kriterijumi važniji od ostalih \\
\hline 5 & $\begin{array}{l}\text { Apsolutna važnost jeclnih } u \text { od- } \\
\text { nosu na druge }\end{array}$ \\
\hline
\end{tabular}

Mogućnosti vrednovanja $i$ ocene pouzdanosti rezultata

Vrednovanje rezultata korišćenja metoda ekspertskih mišljenja je relativno dobro razrađeno. Po pravilu se medijana utvrđuje i koristi kao pokazatelj stava grupe. Medijana je zato pogodnija od matematičkog proseka, jer na ovaj pokazatelj manje utiču suviše niske i suviše visoke vrednosti.

Odgovori koji znatno odudaraju od prosečnog stava grupe pri obradi podataka zaslužuju posebnu analizu, jer se pri statističkoj analizi gubi mišljenje manjine, a ono često predstavlja pravo rešenje.

Pouzdanost dobijenih rezultata tretira se na različite načine. Po jednima, ona se može oceniti samo kada je nastupio događaj, a drugi prilaz je da tre- ba ocenjivati da li je izabrana odgovarajuća metoda i kakav je kvalitet ugrađenih informacija (L.3).

Zajedničke karakteristike od kojih zavisi pouzdanost odgovora su:

- pouzdanost i kompetentnost eksperata, kao i karakter njihovih odgovora;

- prepoznavanja onih slučajeva koji prouzrokuju odstupanja odgovora od stvarnosti;

- dinamika i druge specifične karakteristike razmatranog problema;

- vreme za koje se prognozira razvoj pojave.

Smatra se da je pouzdanost preko $90 \%$ samo $u$ onim slučajevima kada su odgovori dokazana saznanja. Pouzdanost mišljenja normalno se kreće između $30-60 \%$. Pouzdanost pretpostavki je najniža i iznosi $0-30 \%$

Pouzdanost se može poboljšati racionalnim povećanjem broja eksperata, kombinovanjem raznih metoda i nezavisnim radom više ekspertskih grupa na istom problemu.

\section{Intuitivne metode i tehnike}

Praćenjem načina organizovanja i dolaženja do prognoza, ocena programskih orijentacija ili priprema strateških odluka oformljen je veći broj intuitivnih metoda i tehnika. Izložicemo one koje su opšte prihvaćene (L. 1-6).

\section{Brainstorming - konferencija ideja}

Ova metoda je pogodna za iznalaženje rešenja složeníh pitanja društvenog, privrednog i armijskog života. Ovu metodu čini održavanje oknferencije eksperata na kojoj oni traže ideje za rešavanje nekog problema $u$ vezi $s$ kojim se raspolaže sa mnogo informacija. Koliko je konferencija bila uspešna, pokazuje učešće potencijalno korisnih ide- 
ja u ukupnom broju datih ideja. Smatra se da je konferencija bila celishodna ako je učešće korisnih ideja na nivou od 12 do $15 \%$.

Brainstorming se realizuje $u$ sledećim fazama: izbor zadatka, izbor eksperta, pozivanje eksperata, sprovođenje konferencije i obrada rezultata.

Izbor zadatka može da bude $u$ vidu uopštenog ili specijalizovanog pitanja. Treba težiti specijalizovanim pitanjima da bi $i$ odgovori bili konkretniji i da bi procenat korisnosti ideja bio bolji. Uopštena definicija pitanja je prihvatljiva samo ako je bliže definisanje pitanja problematično. U ovom slučaju će i odgovori biti uopšteniji. Prvi rezultat može da se svodi samo na ideje za bliže definisanje pitanja.

$\mathrm{Za}$ brainstorming obično se formira grupa od 12 do 15 eksperata. Poziv eksperata treba da sadrži i kratak opis suštine i ciljeva konferencije i to zbog onih koji još nisu učestvovali u realizaciji sličnog zadatka.

Sprovođenje konferencije je najvažniji deo zadatka. Za to se moraju obezbediti povoljni uslovi rada i klima u kojoj ce svaki slobodno iznositi svoje mišljenje. Upravo zbog toga se učesnici upozore da nisu poželjne kritičke primedbe i komentari. Predsedavajući konferencije mora biti izuzetno vešt. Mora da animira svakog učesnika na aktivno učešće, da inicira i daje i sam ideje, ali da preterano ne ističe svoju ulogu. Trajanje konferencije treba da bude do 90 minuta sa jednim odmorom.

Po završetku konferencije treba obraditi rezultate, izdavanjem predloženih ideja. Prikupljene ideje mogu da idu još na jedno razmatranje učsnicima. Nakon toga vrši se grupisanje ideja po sledećem: ideje koje se mogu odmah realizovati, ideje cija realizacija traži duže pripreme, ideje koje se mogu realizovati $u$ daljoj perspektivi, negativne ideje i nekorisne ideje.
Efikasnost metode (E) utvrđuje se odnosiom broja ostvarljivih predloga (M) i broja ideja (Z)

$$
E=\frac{M}{Z}
$$

Ova metoda može se koristiti efikasno za kratko i srednjoročno predviđanje. Posebno se ističe korisnost $u$ brzom pripremanju donošenja odluka.

\section{Metode Filipsa 66 i Sinektika}

Metoda Filipsa 66 razvijena je varijanta brainstorminga. Eksperti se dele $\mathrm{u}$ grupe od po 6 članova. Svaka takva grupa vodi diskusiju o idejama u trajanju od 6 minuta. Nakon toga sumiraju se i vrednuju ideje na zajedničkom sastanku svih grupa. Prednost ove metode je u tome što je sloboda veća u manjim grupama nego na većoj konferenciji. Međutim, vreme od 6 minuta zadovoljava samo onda ako eksperti dobro znaju problem, ciljeve rada i ako je animator dobar. Inače, potrebno je znatno duže vreme za rad.

Sinektika kao metoda koristi se za rešavanje složenih zadataka. Suština je, takođe, u prikupljanju ideja u grupnom radu (u tzv. sinektičkim grupama).

Izabere se grupa od 5 do 7 esperata kreativnog tipa. Dobijaju jednogodišnje stručno i metodsko osposobljavanje. Sama sintetička konferencija traje dugo, čak i do par nedelja. Metoda, u svojoj suštini, koristi specifičnosti kreativnog razmišljanja. Zadatke analiziraju sa više aspekata $i$ pri tome često koriste analogiju.

Ova metoda se primenjuje uz pomoć posebno pripremljenih eksperata i zato u raspoloživom vremenu mogu dati, relativno sigurne rezultate. Međutim, teren primene je znatno sužen, traži puno vremena i velike troškove. 


\section{Metoda Brainrajting}

Karakteristika metoda opisivanja ideja je u tome što ekspert ima vremena da razmišlja i da kritički analizira svoje odgovore. Prema tome, ovde se ne iznose ideje usmeno nego se napišu. Najčešće se određuje 1 do 2 pitanja. Treba istaći razliku ove metode od klasičnog pismenog ekspertskog mišljenja. Naime, ovde se pišu samo ideje. Rezultati se vrednuju na isti način kao kod brainstorminga.

Varijante opisivanja ideja su i tzv. slobodne i usmerene asocijacije. U ovom slučaju asooijacija se pokreće uzorkom ideja. Može se koristiti upitnik sa i bez povratne veze. Ekspert ima zadatak da proširuje ideje iz uzorka. Kod usmerene asocijacije određuju se i razni kriterịjumi koje eksperti treba da uvažavaju.

\section{Metoda Delfi}

Suština metode je $u$ ispitivanju eksperata. Pri tome eksperti nisu u međusobnom kontaktu i sama anketa je anonimna. Ova metoda je radno intenzivnija, ali i sigurnija od prethodnih metoda u pogledu rezultata. Može biti korišćena sa i bez povratne sprege.

Anketna metoda bez povratne sprege pogodna je za korišćenie ako su potrebne brze informacije ili ako je broj anketiranih jako velik, kao što je to slučaj $u$ ispitivanju javnog mnenja. Primena ove varijante metode ie posebno nreporučliiva ako je reč o pitaniu od šireg društvenog interesa. Primena anketnih metoda sa povratnom spregom posebno je raširena za odlučivanje o nauð̌notehničkim i društveno-ekonomskim problemima.

Osnova metode je u višekratnom ispitivaniu eksperata uz pomoć anketnih listova. U svojoj suštini višekratnost ie uvedena radi analize ekstremnih odgovora. Svaki ekspert ima pravo da ostaje pri svom odgovoru ili da ga koriguje.
Faze $u$ organizovanju primene metode Delfi su:

1) Prvo se određuje koordinator projekta ili grupa za koordinaciju koja ima zadatak da organizuje, sprovede, statistički obradi i analizira rezultate ankete. Sačinjavaju je stručni ljudi za taj posao.

2) Određuje se grupa eksperata koja će biti anketirana. Dovoljam i najpovoljniji broj eksperata kreće se između 10 i 20.

3) Jasno i precizno definišu se pitanja na koje eksperti treba da daju odgovore. Odgovori na postavljena pitanja daju se, najčešce, numerički. Da bi upitnik bio što bolji, poželinno je da koordinator pre niihovog definitivnog sastavljanja konsultuje i eksperte koji ce učestvovati u prognoziranju.

4) Svakom od eksperata dostavlja se Upitnik u kojem su definisana pitania i mesto u koje se upisuju odgovori $i$ jasan i instruktivan opis metode Delfi.

5) Komuniciranie sa ekspertima odvija se tako da nijedan od niih ne zna koii std drugi eksperti koji učestvuiu u pnimeni metode $\mathrm{i}$ kakve su oni odgovore dali (ovo važj za I krug metode).

6) Popuniavanjem unitnika završava se I krug. Dobijeni odgovori sređuju se po pitanjima i statistički obrađuiu (očekivana vrednost $i$ mere disperzije). $\mathrm{Na}$ bazi ovoga. svaki ekspert je u mogućnosti da u II krugu upoređuje svoje odgovore, kao i odgovore drugih (za niega annnimnih) učesnika u metodi $i$ zadatak im je da ponovo daju odgovore na ista pitanja.

7) U II krugu odgovoni na postavliena pitania mogu se i promeniti. II krug završava se statističkom obradom odgovora.

8) Ponavlia se vostudak $i$ na ta $j$ način se završava i III krug, što ie najčešce i završstak primene cele metodo.

Pri izradi kompleksnih prognoza razvoja većih sistema rukovodstvo projekta (primenom Brainstorming meto- 
de, i dr.) odreduje dominantne faktore (ljudski faktor, materijalna baza, organizacija, spoljašnji uticaji, i dr.). Za ove faktore u prvom upitniku se vrši izbor događaja i pojava koji se mogu očekivati, zavisno od postavljenog cilja prognoze. Izbor se vrši prema medijani iz predloženog šireg spiska predlcga dobivenih anketom.

U drugom upitniku vrši se određivanje vremenskog horizonta - intervala nastupanja prognoze za događaje, odnosno veličine \% pozitivnih $j$ negativnih odgovora za pojave (tendencije).

Vrednovanje događaja i pojava vrši se u trećem upitniku sa 3 do 5 gradacija, iz aspekta:

a) Važnosti

- nije važno

- malo važno

- izuzetno važno

b) Ostvarljivost

- neostvarljivo

- uslovi delimiěno postoje

- uslovi u potpunosti povoljni

c) Verovatnoće

- mala verovatnoća $(0,1-0,3)$

- prosečna $(0,5)$

- velika verovatnoća $(0,8-1)$.

$\mathrm{U}$ ponovljenim upitnicima daje se srednja vrednost (prosečno mišljenje grupe) i interkvartalno područje (IQR) u koje spada $50 \%$ prosečnih mišljenja. Učesnici čija su mišljenja izvor IQR područja treba da navedu argumente za svoj stav i daju novi odgovor u kome mogu da promene ili da ostanu pri svom ranijem odgovoru.

$\mathrm{Na}$ kraju svakog kruga vrši se $\mathrm{i}$ vrednovanje odgovora: Više krugova se održava radi ujednačavanja ekspertskih stavova. $\mathrm{Na}$ pitanjima gde ne dolazi do ujednačavanja stavova, vrši se posebna analiza.
Posle paslednjeg kruga sledi matematičko-statistička obrada rezultata. Pri tome se koristi: grupisanje odgovora, sistematizacija, rangiranje, medijana, standardna devijacija i koeficijent varijacije

Praktični primeri dokazuju da je moguće raditi sa svega $5-6$, ali i sa više od 100 eksperata. Istraživanja pokazuiu da se pouzdanost odgovora grupe naglo povećava pri povećanju broja eksperata do 22-25, a nakon toga beznačajno.

Anketni listovi i pitanja treba da su jednoznačna, jednostavna, razumljiva i ne preobimna. Iskustva pokazuju da nije celishodno koristiti više od 25 do 30 pitanja.

Broj anketnih krugova predstavlja poseban problem. Međutim, to zavisi od približavanja stavova eksperata i njihovog odnosa prema korigovanju stavova.

Za utvrđivanje broja krugova koristi se pokazatelj koji se može nazvati koeficijentom konzistentnosti. To se izražava sledećom formulom:

$$
\mathrm{S}=\frac{\mathrm{Sk}+1}{\mathrm{Sk}}
$$

gde je:

$\mathrm{Sk}=$ prosečno adstupanje $\mathrm{u} \mathrm{k}$-tom krugu;

$\mathrm{Sk}+1=$ prosečno odstupanje u $k+1$ krugu.

Ukoliko je $\mathrm{SK}=0$ nije potrebno dalje anketiranje, jer je konzistentnost stavova potpuna. Ukoliko je $\mathrm{Sk}+1=0$, dalje anketiranje nije potrebno jer se došlo do sporazuma oko zajedničkih stavova. Ukoliko je $S=1$ dalje anketiranje nije potrebno, jer eksperti ostaju pri svojim stavovima $(\mathrm{Sk}+1=\mathrm{Sk})$. Praksa pokazuje da se može zanemariti sledeći krug ukoliko je $0,75<S<1,25$.

Međutim, treba imati $u$ vidu da prijem novih informacija između dva kruga može menjati stav eksperta, što ce 
smanjiti koeficijent konzistentnosti. To može da pokaže potrebu novog kruga i umanjivanje stepena približavanja stavova eksperata. Iz tih razloga najčešće se pribegava korišćenju promena vrednosti medijane koja zanemaruje ekstremne vrednosti.

Prema kreatorima metode Delfi za solidnu konzistentnost stavova potrebno je 5 krugova. To je dovoljan broj iternacija da bi došao do izražaja i međusobni uticaj stavova eksperata. Iskustva pokazuju da se konzistentnost može postići i sa manjim brojem krugova.

\section{Metoda SEER}

Metoda Delfi razvijena je za specijalne namene $u$ raznim varijantama. Jedna varijanta je sistem za procenu događaja $i$ analizu (System for Event Evaluation and Review), odnosno metoda SEER. Ova metoda predstavlja jedan vid pisanog $i$ usmenog ispitivanja eksperata i otklanjanje nekih nedostataka metode Delfi. Naime, metoda DeIfi zahteva puno vremena, ekspertima nije uvek jasan cilj postavlianja pitanja, ne vrednuju se interakcije, kratkoročni : dugoročni ciljevi, potrebni uslovi i sredstva. Tehnika metode SEER je, takođe, jednostavna. Izvodi se u dve faze:

- u prvoj fazi se priprema uzorak predviđanja i predlozi za donošenje odluke na bazi stavova stručnjaka u samoj organizaciji i prema literaturi. Ovako pripremljeni uzorak dostavlja se ekspertima na dopunu i vrednovanje po određenim zadatim kriterijumima. $\mathrm{Na}$ osnovu dobijenih rezultata uspostavlja se »banki podataka«, sređena po adređenim kriterijumima:

- u drugoj fazi upit se postavlja heterogenom sastavi eksperata. Među njima mogu ucestvovati i eksperti iz prve faze. U ovoi fazi eksperti rade po principu normativizma i imaju zadatak da vrednuju uzorak sa drugih aspekata, da skiciraju interakcije predvi- đenih događaja, da definišu sistem ciljeva. Na osnovu vrednovanja dobijenih odgovora može se definisati model putem do cilja, iz kojeg će se jasno videti sve ono što treba realizovati za ostvarivanje nekog cilja. Metod je relativno jednostavan za učesnike, ali zahteva veoma ozbiljno angažovanje animatora $u$ definisanju modela puta do cilja.

$\mathrm{Na}$ osnovu obrađenih podataka rukovodstvo projekta radi stablo SEER, počevši od daljeg vremenskog horizonta prognoze do početnog. Najčešce se radi sa 3 ili 2 vremenska perioda. Kod ovoga od izabranih događaja i pojava za sve faktore prognoze, oni koji su najznačajniji pretvaraju se u ciljeve, a ostali u nužne ili željene uslove. Ova transformacija $i$ unutrašnje povezivanje između njih na jednom nivou i između vremenskih horizonata stvaralački je rad radnog tima. Sema stabla SEER prikazana je na sl. 1.

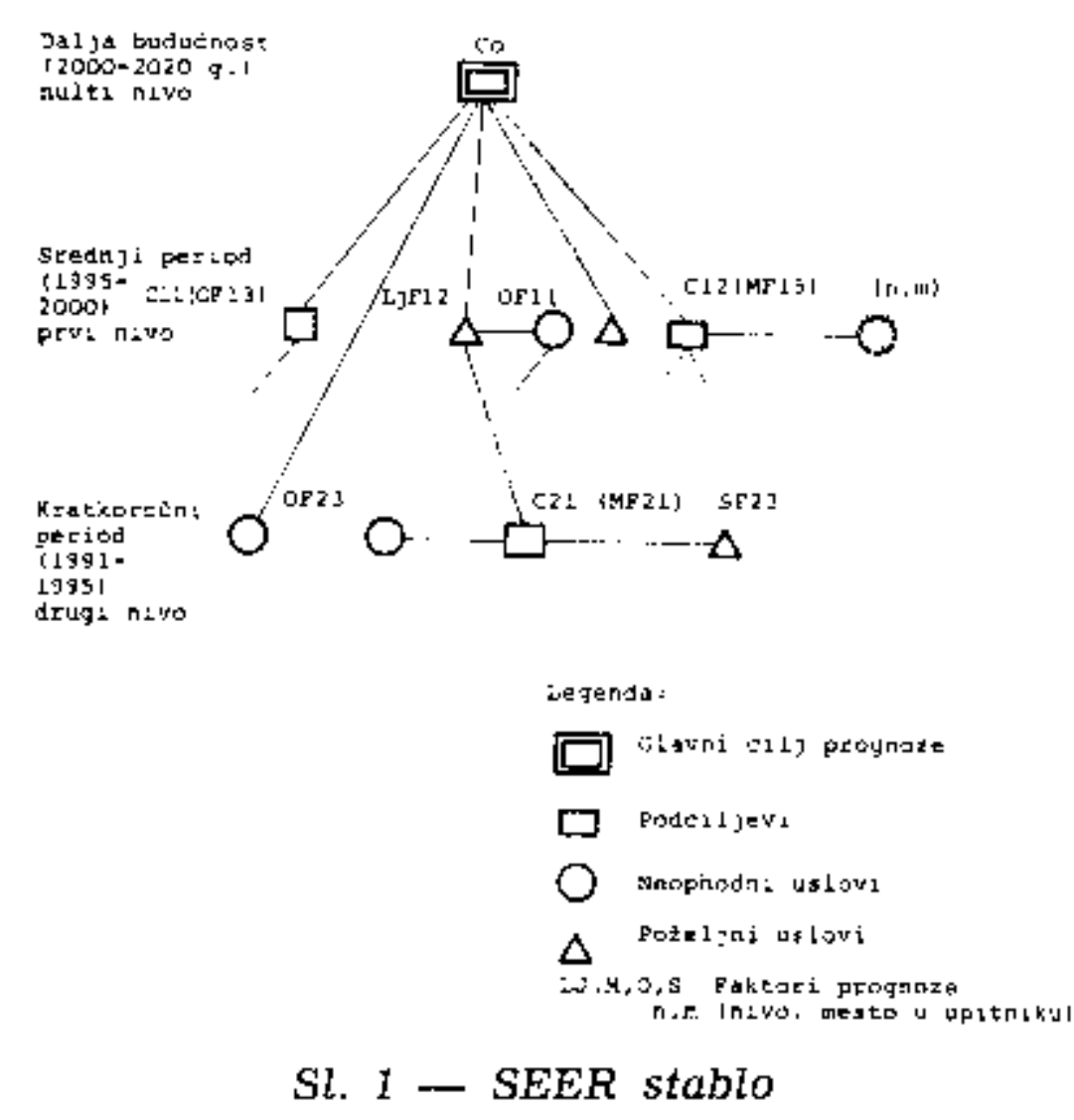

Pri analizi puteva za ostvarivanje ciljeva definisanih stablom SEER ide se od sadašnjosti, uz ocenu neopohodnih i željenih uslova i predviđanjem potrebnih aktivnosti. 


\section{Metode u ubradi podataka ankete}

\section{Statistički pokazatelji ankete}

Obrada rezultata ankete eksperata zavisi od oblika informacije dobijene od eksperata (L. 1).

Ako svaki od $N$ eksperata, koji uceestvuju $u$ anketi, daje (po zahtevu ankete) jednu vrednost $y_{j}(j-$ broj datog eksperta) buduće vrednosti prognozirane veličine, to će u rezultatu obrade $\mathrm{N}$ vrednosti $\mathrm{y}_{\mathrm{j}}$ moći da se dobiju sledeći pokazatelji:

- srednja vrednost ekspertnih ocena (tačkasta prognoza date grupe eksperata), koja karakteriše prosečno mišljenje eksperata:

$$
\hat{\mathrm{y}}_{\mathrm{o}}=\frac{1}{\mathrm{~N}}-\Sigma \mathrm{y}_{\mathrm{i}}
$$

- disperzija ocena, koju karakteriše dijapazon stavova (tačkasta prognoza) pojedinih stručnjaka u odnosu na srednju vrednost $y_{b}$ :

$$
\hat{D}(y)=\frac{1}{N-1} \sum_{j=1}^{N}\left(y_{p}-y_{i}\right)^{2}
$$

- srednje kvadratno odstupanje koje karakteriše navedeno rasturanje, koje se dimenziono podudara sa veličinom $\mathrm{y}$ :

$$
\hat{\sigma}=\sqrt{\hat{D}(y)}
$$

- koeficijent varijacije, koji može da karakteriše stepen jednodušnosti stručnjaka:

$$
\mathrm{V}=\frac{\hat{\sigma}}{\mathrm{y}_{\mathrm{o}}}
$$

Ukoliko je veličina v manja, utoliko se većom može smatrati jednodušnost eksperata.

Pri obradi rezultata ankete treba imati u vidu još i sledeće: protivrečnost mišljenja može se objasniti oko-
Inošću da odgovarajući stručnjak bolje od drugih zamišlja razvoj prognoziranog procesa u budućnosti i zato »ispadak iz oblasti koja karakteriše mišljenje njegovih kolega. Zato se prema krajnjim tačkama ankete eksperata treba odnositj veoma pažljivo: proučivši temeljno zaključke stručnjaka $u$ korist svojih ocena, s tim mišljenjem treba upoznati i druge stručnjake. $\mathrm{Na}$ taj način, redosled dejstava pri oceni rezultata ankete stručnjaka koji daju prognoze $y_{j}(j=1,2,3 \ldots N)$ o budućoj vrednosti prognozirane veličine može biti sledeći:

- određuje se uopšteno (generalizovano) mišljenje eksperata (tačkasta prognoza) pomoću izraza (3);

- određuju se disperzija i srednje kvadratno odstupanje mišljenja eksperata pomoću izraza (4) i (5);

- vrši se ocena protivrečnosti krainjih mišljenja eksperata pomoću logičke analize;

- pri neprotivrečnim mišljenjima eksperata rezultati ankete se oformIjuju $\mathrm{u}$ vidu tačkaste prognoze (3);

- pri protivrečnim mišljenjima vrši se drugi krug anketa (sa ocenom rezultata i mišljenja prvog puta) radi usaglašavanja ssa članovima date grupe eksperata (ili po upotrebi i sa dovođenjem novih eksperata).

Tačnije if radije pribvaćen, od stručnjake, oblik ocenjivanja - jeste dobijanje mogućih granica prognozirane veličine. Ako svaki od $\mathrm{N}$ stručnjaka koji učestvuju u anketi daje dve vrednosti (minimalnu $y_{j}{ }^{\min }$ i maksimalnu $\mathrm{y}_{j}{ }^{\text {max }}$ ) među kojima ce se o njegovom mišljenju nalaziti buduća vrednost prognozirane veličine, to obrada rezultata ankete može biti sprovedena na sledeci način: pre svega, neophodno je usvojiti oblik zakona raspodele prognozirane veličine među krajnjim ocenama svakog stručnjaka. Naročito, u svojstvu 
takvog apriori zakona raspodele može biti izabran zakon ravnomerne gustine (L. 7):

$$
\begin{aligned}
& f_{(y)}=\frac{1}{y_{j}{ }^{\max }-y_{j}{ }^{\min }} \\
& y_{j}{ }^{\min } \leqslant y_{j} \leqslant y_{j}{ }^{\max }
\end{aligned}
$$

$f\left(y_{j}\right)=0$ u svim ostalim slučajevima.

Pri tome, srednja vrednost (tačkastaprognoza), data j-ekspertom, određuje se prema formuli:

$$
\mathrm{y}_{\mathrm{j}}=\frac{1}{2}\left(\mathrm{y}_{\mathrm{j}}^{\max }+\mathrm{y}_{\mathrm{j}}^{\min }\right)
$$

Tačkasta pxognoza cele grupe eksperata (pri jednakom poverenju u svakog od njih), saglasno izrazu (3), biće:

$$
\mathrm{y}_{\mathrm{o}}=\frac{1}{\mathrm{~N}} \hat{\mathrm{J}}=1_{\mathrm{N}}^{\mathrm{N}} \hat{\mathrm{y}}_{\mathrm{j}}
$$

Rasturanje tačkastih prognoza pojedinih eksperata $u$ odnosu na $y_{\circ}$ nalazi se iz izraza

$$
\hat{D} y=\frac{1}{N-1} \sum_{j=1}^{N}\left(y_{o}-y_{j}\right)^{2}
$$

a koeficijent varijacije koji karakteriše jednoduśnost eksperata u pogledu tačkastih prognoza nalazi se prema izrazu (6).

Pored razmatranih vrsta ocena koje daju eksperti pri prognoziranju, može biti i takav slučaj (mada se znatno ređe sreće) kada eksperti daju tri ocene (L. 4),

Tada događaj y podleže beta-raspodeli. Za ovu raspodelu očekivana vrednost $t_{j}\left(y_{j}\right)$ i disperzija $\sigma_{j}{ }^{2}$ odgovora svakog stručnjaka računa se pomoću sIedećih obrazaca:

$$
\hat{t}_{j}=\hat{y}_{j}=\frac{\gamma_{j} \cdot O_{j}+\gamma_{2} \cdot m_{j}+\gamma_{3} \cdot P_{j}}{\gamma_{1}+\gamma_{2}+\gamma_{3}}
$$

gde je $\mathrm{t}_{\mathrm{j}}=\mathrm{y}_{\mathrm{j}}=$ aritmetička sredina $=$ = očekivana vrednost, po Pert-metodi: $\gamma_{1}=1, \quad \gamma_{2}=4$, $\gamma_{3}=1, \quad \gamma_{4}=36$.
Jednačina za meru disperzije, glasi:

$$
\sigma_{j}^{2}=\frac{\left(P_{i j}-O_{j}\right)^{2}}{\gamma_{4}}
$$
biće:

Ukupna srednja očekivana vrednost

$$
\hat{y_{0}}=\frac{1}{N_{j=1}^{N}}-\mathrm{y}_{j}
$$

Jednačina za ukupnu disperziju glasi:

$$
\sigma^{2}=\frac{1}{N}\left[\sum_{j=1}^{N} \sigma_{j}^{2}+\sum_{j=1}^{N}\left(y_{j}^{2}-y_{N}^{2}\right)\right]
$$

Mišljenja elksperata o postavljenim pitanjima se iz kruga u krug sve više usaglašavaju. Rezultati ankete statistički se obrađuju i stvaraju se uopštene karakteristike, koje izražavaju postignutu saglasnost mišljenja prema faktoru - vreme. (L. 8).

Statističko raspoređivanje pretpostavljajućih mišljenja iskazuje se na taj način što je vremenski interval među kvartiljima prognoze $u$ prvom približavanju jednak očekivanom intervalu pomicanja unapred, ograničenom medijanom. Na primer, ako je medijana raspoređena na $\mathrm{y}_{\mathrm{o}}$ godina unapred od vremena kada je prognoza sačinjena, to se donji kvartili ispoljava na distanci $2 / 3$ yo od početka odbrojavanja, a gornji kvartilj na rastojanju $5 / 3$ yo. $\mathrm{Na}$ taj način je rastojanje među kvartiljima opet jednako yo godina (sl. 2).

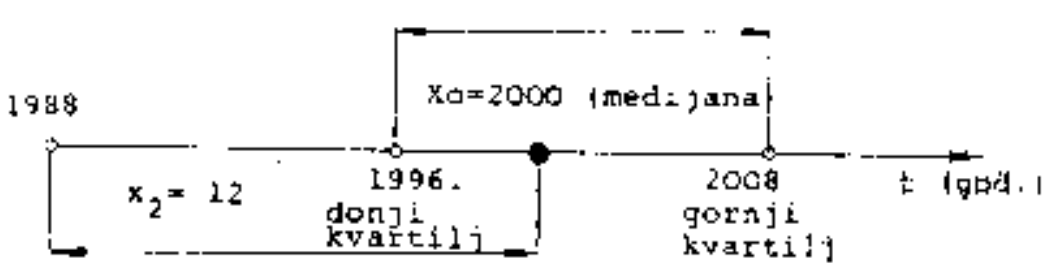

Sl. 2 - Određivanje granica kvattilja

Interval među kvartiljima mora se smanjivati $u$ meri postizanja uspeha $u$ toku ponavljanja procesa ankete. Prosečno značenje odnosa krajnjeg kvartiljnog rastojanja prema početnome iznosu $5 / 8$. 
Osnovna vrednost metoda Delfi sastoji se u korišćenju širokag broja procena prognoze, što pruža moguénost za proračunavanje:

- značenje medijana i kvartiljas

- mogućnosti smanjenja intervala kvartilja;

- korelacije među dve procene datuma realizacije otkrića s verovatnoćama 50 i $90^{\circ} \%$, što pretpostavlja postojanje tajnih »psiholoških veza« među njima. Pri tome je odnos medijana ravan: $\mathrm{M}(0,9) / \mathrm{M}(0,5)=9 / 5=1,8$, a odgovarajući odnos za donje i gornje kvartilje 1,6 i 2,0 .

\section{Pokazatelji kompetentnosti eksperata}

U principu, prema rezultatima ankete eksperata, mogu biti izračunata neka matematička obeležja koja karakterišu kompetentnost i temperament određenih eksperata.

Takva obeležja mogu biti :

- koeficijent varijacije

$$
\mathrm{v}_{\mathrm{j}}=\frac{\sqrt{\mathrm{D}_{\mathrm{j}}\langle\mathrm{y})}}{\hat{\mathrm{y}}_{\mathrm{j}}}
$$

gde fe:

$$
\mathrm{D}_{\mathrm{j}}(\mathrm{y})=\frac{1}{12}\left(\mathrm{y}_{\mathrm{j}}^{\mathrm{max}}-\mathrm{y}_{\mathrm{j}}^{\mathrm{min}}\right)^{2}
$$

koja karakteriše odlučnost (ubeđenost) eksperata u svoju ocenu (ekspert sa manjom vrednošcu $v_{j}$ kategoričniji je $u$ svojoj oceni), a posredno karakteriše i kompetentnost odredenog eksperta (ukoliko se ekspert dublje razume $u$ dato pitanje, utoliko se granice $y_{j}^{\max } i y_{0}^{\text {min }}$ više približavaju ka fizički mogućim granicama buduce vrednosti prognozirane veličine):

- velicina

$$
\varepsilon_{j}=\frac{\hat{y_{j}}-\hat{y}_{o}}{y_{o}}
$$

koja karakteriše kako kompetentnast j-eksperta sa gledišta u datom trenutku vremena postignutog nivoa znanja o prognoziranom objektu, koja se izražava U veličini yo (ekspert sa manjom vrednošću $\varepsilon_{\mathrm{j}}$ može da se smatra kompetentnijim), tako i neke njegove karakterne crte - oprezni ekspert ima negativnu vrednost (ako razvoj ide $u$ smeru povećanja y), pošto je $\hat{y}_{j}-\hat{y}_{o}<0$, dok istovremeno smeliji ekspert daje ocenu koja je veća od $y_{0} i$ njegovo $\varepsilon_{j}>0$. Polazeći od dosad izloženog, možemo reći da su najpoželjniji stručnjaci sa, po modulu, manjim vrednostima navedenih obeležja. Pored obeležja koja karakterišu kvalitet pojedinih stručnjaka, mogu biti dobijena i obeležja koja karakterišu kvalitet celokupne grupe eksperata kao celine.

Jedno od takvih obeležja jeste koeficijent varijacije koji karakteriše isto mišljenje stručnjaka u odnosu na uopštenu tačkastu prognozu, a koji se određuje izrazom (6). Povećanje tog koeficijenta svedoči o razilaženju eksperata u mišljenjima. Međutim, ovo razilaženje može imati različitu prirodu. Ono može biti »ravnomerno«, tj. mišljenja stručnjaka mogu ravnomerno da ispunjavaju celokupnu oblast između krajnjih tačkastih prognoza. U tom slučaju, razilaženje stručnjaka u mišljenjima može postojati kao objektivna posledica prirode prognoziranog procesa (uticaj velikog broja neodredenosti koje prate prognozirani proces, a koje nisu proučene do današnjeg trenutka vremena), kao i posledica nedovoljne kompetentnosti niza stručnjaka koji učestvuju $u$ anketi.

Koeficijent varijacije se, takođe, povećava, ako postoji nekoliko (po pravilu dve) grupa mišljenja, makar da su u svakoj grupi stručnjaci međusobno istomišljenici. Iako se u prvom slučaju (pri ubeđenosti u kompetentnost stručnjaka) možemo koristiti njihovim uopštenim mišljenjem, $u$ drugom je potrebno preduzeti mere za usaglašavanje mišljenja stručnjaka (putem izvo- 
đenja ponovne ankete sa ocenom rezultata prve, dovođenja drugih eksperata, itd.). Razilaženje drugog tipa može postojati, naročito, ako pri anketi nisu bili obezbeđeni uslovi za dobijanje nezavisnih ocena (uticaja međusobnog opštenja stručnjaka, mišljenje autoriteta, itd.).

\section{Zaključak}

Izložena organizacija i metode korišćenja ekspertskih mišljenja za prognoziranje i pripremanje donošenja odluka, pored teoretske osnove, sadrže $i$

Literatura:

[1] Cujev J. V. 1 dr.: Prognoziranje u vojsci, Vojnó izdavackki zavod, Beograd, 1980.

[2] Somodjł dr s.: Metodi ekspertskih milljenja u pripremanju i donošenju odluka, Direktor br. 3 , Beograd, 197.

[a] Kovaæ dr O., Novak dr E.; Suština, značaj i metodł prognoziranja, Semlnar EPCD, Beograd, 1989.

[4] Cuk mr D.: Budućnost i trendovi razvoła automatske obrade podataka - Primena Delfi metode, Organizacija rada br. 5, SITJ, Beograd, 1977 . praktična uputstva za primenu u praksi.

Pri tome, treba imati u vidu da su promene koje se dešavaju u razvoju društva $i$ oružanih snaga tako nagle, sve veće $\mathrm{i}$ brže. da se javlja opravdana potreba za njihovim predviđanjem i usmeravanjem. S druge strane, od pouzdanosti predviđanja zavisi pravilno determinisanje buduceg razvoja, odnosno planiranje. Osnovni cilj svakog planiranja jeste da bude što pouzdanije, a da bi se to ostvarilo, potrebno je da se koriste naučno osnovane metode prognoziranja i pripremanja odluka.

[5] Postupci naucnotehnickog predvidanja, Savesna privredna komora 1 Institut za naučnotehnicki1 dokumentaciju 1 informacije, Beograd, 1990 .

[6] Miladinovíć dr V.: Predviđanje - prognozirarje razvoja, Centar visokih vojnih škola, Beograd, 1992.

[7] Vukadinovic dr. S.: Matematicka statistika, PDS saobraćajn1 fakultet, Beograd, 1971.

[8] Skugarjev D. i dr.: Nauka o upravljanju i mornariç, Vojnotzdavačkł zavod, Beograd, 197j 